ГЕНОМ И ЕГО РЕГУЛЯЩИЯ

\title{
The epigene hypothesis
}

\author{
Rustem N. Tchuraev \\ Institute Biology Ufa Science Centre of the Academy of Science of the Russia \\ 69 Prospect Octyabrya, Ufa 450054, Russia
}

\begin{abstract}
The possibility of storing hereditary information outside DNA genome molecules is discussed. A hypothesis of epigene as a unit is put forward. According to this hypothesis: a) hereditary information is coded for not only by the sequences of DNA nucleotides, but also by other means such as the presence or absence of some regulatory proteins; b) storage of hereditary information during the cell life cycle is provided by the feedback mechanism; c) the information inherited from parents to offspring is transmitted through the distribution of extragenomic macromolecules of regulatory substances. Models of the simplest systems with epigenic properties are considered. Depending on the concrete state of epigenes observed in different states and individual ontogenetic patterns, intercrosses may produce the following effects: 1) absorption (offspring will have epigenes in similar states; 2) formation of epiheterozygotes yielding gametes of various kinds; 3 ) formation of variants each reproducing gametes of only one kind and the variants producing different kinds of gametes. To detect epigenic effects the special interbreeding experiments are suggested.
\end{abstract}

One of the basic suggestions of modern molecular biology is the concept that hereditary information is encoded by nucleotide sequences of DNA genome molecules. However, this does not rule out the possibility of other ways of coding and storing hereditary information. It is generally accepted that information may be stored either by maintaining a definite distribution pattern of elements of spatial structure (structural way) or by circulation of signals in the cyclic system of elements (dynamic way). In DNA molecules information is stored by a structural way. This paper is concerned with discussion of the possibility of storing a part of hereditary information by the dynamic way, outside DNA molecules. It should be noted that DNA molecules code for the structure of dynamic devices responsible for storing information.

The term «structural gene» will imply a bound part of DNA molecule coding for the structure of a certain protein or RNA. Some genes may be either in the active or non-active state differing in the intensity of mRNA synthesis. Genes can form systems by means of regulatory proteins. Of special interest are cyclic gene systems having at least two functional states and capable of maintaining each state both during the cell life cycle and successive cellular divisions.

(C) R. N. TCHURAEV, 1997
Such systems really exist. An illustrative case of the cyclic system of this kind is the two-operon molecular trigger in $\lambda$-phage (Fig. 1) $[1-3]$. This system has two stable states: the first - operon $L_{1}$ is switched on, $R_{1}$ is switched off; the second state operon $R_{1}$ is switched on, $L_{1}$ is switched off. The first state of the system corresponds to the immune (lysogenic) state of prophage when there is suppression of the lytic growth of phage genomes penetrating anew into the bacterial cell of the same prophage strain. The second state of the system corresponds to the nonimmune (lytic) state of the prophage when reduplication of superinfected phage genomes is possible. The first of these states is maintained both during the host cell life and its successive divisions. In the lytic state the phage undergoes a number of successive reduplication cycles. This system presents an example of a especially here - ditary unit, wherein the genome is responsible only for the possibility of a system being in one of the inheritable states, while the concrete state of the initial prophage and daughter phage genomes is determined by the presence or absence of the respective repressor $[1,4]$.

Epigene will be defined as a hereditary unit (cyclic system) responsible for the activity of the respective gene (or genes) and having at least two alternative states which may be maintained in a successive number of generations. Moreover, the transition from one state to another is not necessarily 


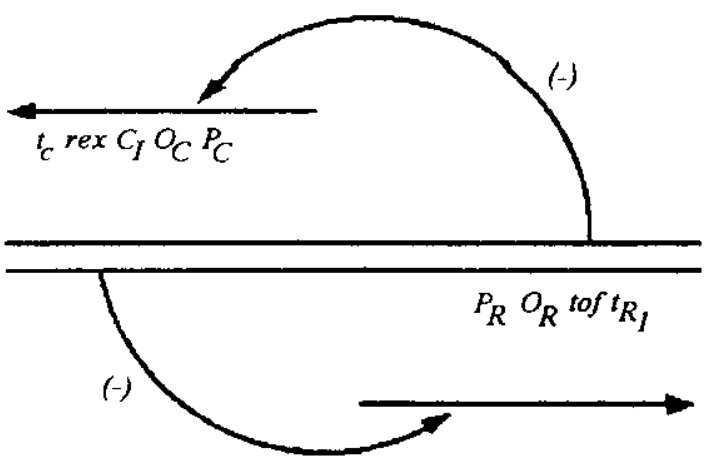

Fig. 1. Molecular trigger of the $\lambda$-phage. Protein products of genes $C_{1}$ and tof are repressors for scriptons $R_{1}$ and respectively. Only the first zone of the scripton $R_{\mathrm{I}}$ is depicted

accompanied by a change of the DNA structure, while maintenance of each state is the system property. If the system passes from one state to another due to some exterior factors, the state the system has passed to is maintained also after these factors cease affecting it. The existence of epigenes in prokaryotes does not raise any doubts. The illustrative case is twooperon trigger systems in lambdoid phages. We shall consider the possibility of existence of epigenes in eukaryotes. In this case, some genes of a multicellular organism should be subordinated to systems (that is, they are either embodied by these systems or connected with them via direct bonds) capable of maintaining whether an active or inactive state through successive cell divisions and formation of offspring in a successive generation. It should be emphasized that the choice of the system state must not be determined (directly or indirectly) by genes embodied by these systems.

Let us analyse the simplest systems possessing the properties of epigenes which will serve an illustration of some inferences drawn from the hypothesis of the existence of epigenes.

One-Component Model. Let us firstly consider the simplest cyclic system composed of one transcription unit - a scripton (Fig. 2). A scripton is assumed to contain a receptor zone having an affinity for regulatory proteins (i. e. it is an operon), one or several structural genes and a regulatory gene producing a stable protein activator of the transcription of the same operon. At sub threshold concentrations of the activator, no effective transcription occurs; at concentrations higher than threshold, it does occur. Such a system has two alternative states. Each state is preserved during cell life and transmitted to daughter cells through successive divisions when the state of the daughter cell system is determined by the

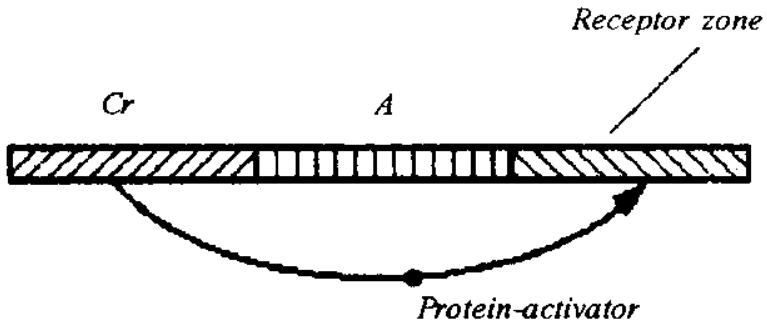

Fig. 2. One-component model of epigene: $A-$ structural gene; $C_{r} \rightarrow$ gene-regulator, coding the protein-activator

presence or absence of the activator protein in the parental cell, that is, by the state of the parental cell system. In this case, the succession or "inheritance» of the system state is provided by the transfer of activator proteins from the parental to daughter cells, wherein they induce transcription of the scripton. Such one-component model has a real prototype. The protein $C_{1}$ of $\lambda$-phage activates transcription of the operon containing the cistron $C_{1}[5]$.

Eukaryotes possess some essential features which may affect the capacity of cyclic systems to be epigenes. The inheritance of system state in eukaryotes includes the inheritance through cell lines, that is, through mitoses and gametes. In the latter case, each state of the system should be preserved during meiosis, gametic stage, fertilization and early stages of embryogenesis.

The inheritance of the active state through cell lines is provided by the production of activator proteins during each cell cycle and their distribution among daughter cells. In the case of gametogenesis, the situation is more complex.

During gametogenesis and at the early stages of embryogenesis, many loci may be completely repressed (for example, as a result of chromosome coiling). In the case of one-component model, this will not affect the maintenance of the inactive state. As for the alternative state, activator proteins and the respective mRNAs will be kept diluted with each cell cycle. For this reason, inheritance of the active state is possible only when transcription and translation are turned off for a period of time not exceeding that of the total dilution of activator proteins. An important feature of eukaryotes is the existence of very stable mRNAs [6]. The translation of such mRNAs can take place even when there is no transcription at the respective loci. Hence, if the epigene contains a stable mRNA the 
period of dilution of activator proteins in the absence of transcription may be sufficiently protracted. In general, transcription and translation are perhaps not altogether effaced during gametogenesis and early embryogenesis [6]. Maintenance of the state of epigenes which are not turned off by systems of a hierarchically higher level, occurs the same way as in the case of inheritance through cell lines.

Most eukaryotes are diploids, and in diploid cells genes form pairs. We assume that the homologous genes included in epigenes do not differ structurally, that is, the organism is homozygous for these genes. The state of a gene, included in the epigene, will be designated by a binary upper index next to the gene symbol. Thus, $A^{1}$ will stand for the active state of the gene $A$ and $A^{0}$ will refer to its inactive state. The term "epigenotype» will denote a list of all the genes included in an epigene with an indication of their states. Organisms, of the same genotype may have different epigenotypes. Thus, in the case of onecomponent model, individuals with genotype $A / A$ may have epigenotypes $A^{1} / A^{1}$ and $A^{0} / A^{0}$. This means that in all the cells of the organism the gene $A$ has either an active (with the first epigenotype) or inactive (with the second epigenotype) state. These individuals produce gametes of one kind, $A^{1}$ or $A^{0}$. The more complicated cases will be considered below. Phenotypically, individuals with the epigenotype $A^{0} / A^{0}$ will look as a recessive homozygote while individuals with the epigenotype $A^{1} / A^{1}$ - as a dominant homozygote.

Let us examine crosses between individuals, taking into account their epigenotype.

$$
\text { 1. } A^{0} / A^{0} \times A^{0} / A^{0} \rightarrow A^{0} / A^{0} \text {. }
$$

The partners form gametes containing no activator proteins.

$$
\text { 2. } A^{1} / A^{1} \times A^{1} / A^{1} \rightarrow A^{1} / A^{1} \text {. }
$$

In this case activator proteins from gametes will enter into a zygote.

$$
\text { 3. } A^{1} / A^{1} \times A^{0} / A^{0}-\rightarrow A^{1} / A^{1} \text {. }
$$

In the latter case, due to the free migration of the activator, the inactive epigene will pass into an active state.

Phenotypically, this will appear as a transition of one allele into another. This unification of epigene states will be called absorption. The absorbed «hybrids» of the first generation will produce gametes of the same kind, and epigenotype $A^{0} / A^{0}$ will not appear in subsequent crosses, that is, segregation does not occur.

As a result of the inconsiderable content of cytoplasm in a male gamete, its capabilities to transfer activator proteins are limited. The capacity to transmit an active state through a male gamete depends on the effectiveness of activator proteins. If the affinity of activator proteins for the respective receptor zones is as strong as in the case of some regulatory molecules in bacteria [7], a small amount of the activators passed from the male gametes is capable of providing transmission of an active state. In the case of a small affinity, an active state cannot be transmitted through male gametes. Therefore, inheritance of epigene states in some individuals may occur only through maternal lines.

Epigenes may accidentally change their functional state and structure. Thus, new functional state can be absorbed during crosses between individuals containing epigenes in different states. Structural changes (mutations) may affect the structural gene included in the scripton, receptor zone and the regulatory gene. Mutations of the structural gene result either in inactivation of the product of this gene (a phenotypically mutant gene does not manifest itself) or in the change of some characteristics of the product without its inactivation (a phenotypically mutant gene manifests itself). In the case of inactivation of the product, the active and inactive states of the mutant gene are phenotypically indistinguishable; but the results of some crosses will depend on the state of this gene. For example, we may obtain the following two crosses:

$$
A^{0} / A^{0} \times a^{1} / a^{1} \rightarrow A^{1} / a^{1} ; A^{0} / A^{0} \times a^{0} / a^{0} \rightarrow A^{0} / a^{0},
$$

where $A$, is a nonmutant gene and $a$ is a mutant gene. As a result of the absorption, the gene $A$ manifests itself in the former hybrid, whereas in the latter - it does not.

We are now concerned with the case when the structural gene mutation results only in the change of some characteristics of the product, and the mutant gene in an active state manifests itself in individuals containing in a homologous chromosome a normal allele of this gene in an active state. For two alleles $A_{1}$ (normal) and $A_{2}$ (mutant) of the structural gene, six epigenotypes:

$$
A_{1}{ }^{1} / A_{1}{ }^{1}, A_{1}{ }^{0} / A_{1}{ }^{0}, A_{1}{ }^{1} / A_{2}{ }^{1}, A_{1}{ }^{0} / A_{2}{ }^{0}, A_{2}{ }^{1} / A_{2}{ }^{1}, A_{2}{ }^{0} / A_{2}{ }^{0} \text {, }
$$

and 4 phenotypical classes are possible. Mutations of the receptor zone of the scripton and the regulatory gene may be responsible for the case where the activator of each epigene is specific only to the receptor zone of its epigene, the diversity of the possible epigenotypes increases and assumes the following form:

$$
\begin{gathered}
A_{1}{ }^{\mathrm{j}} / A_{1}{ }^{\mathrm{j}}, A_{1}{ }^{0} / A_{1}{ }^{0}, A_{1}{ }^{\mathrm{j}} / A_{2}{ }^{1}, A_{1}{ }^{0} / A_{2}{ }^{\mathrm{j}}, A_{1}{ }^{1} / A_{2}{ }^{0}, A_{1}{ }^{0} / A D_{2}{ }^{0}, \\
A_{2}{ }^{1} / A_{2}{ }^{1}, A_{2}{ }^{0} / A_{2}{ }^{0} .
\end{gathered}
$$




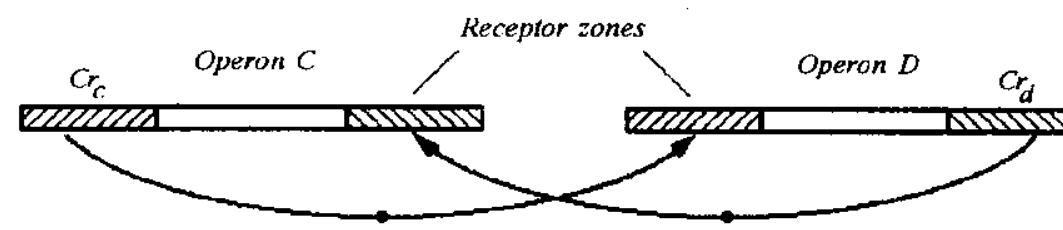

Fig. 3. Two-operon trigger: $d-$ repressor of the operon $D$ transcription; $c$ - repressor of the operon $C$ transcription
Two-Operon Trigger. We proceed next to the simplest cyclic system possessing the properties of the epigene (Fig. 3). This system is a two-component trigger suggested for the first time by Monod and Jacob [8]. Later on, the models of such systems were investigated by different methods $[9,10]$.

It was shown that they have two alternative states. In the system, described in Fig. 3, both components contain a regulatory gene, the protein product of which represses the activity of the other component.

We are now examining an epigene presented by such a cyclic two-component system. Let both genes of the system be located on a chromosome, and the repressors of the trigger are stable proteins. Crosses between individuals of the same epigenotype will yield offspring with the parental epigenotype. For example,

$$
C^{1} D^{0} / C^{1} D^{0} \times C^{1} D^{0} / C^{1} D^{0} \rightarrow C^{1} D^{0} / C^{1} D^{0} .
$$

In crosses between individuals which different epigenotypes, $C^{1} D^{0} / C^{1} D^{0} \times C^{0} D^{1} / C_{0} D_{1}$ the epigenes will behave in a complex fashion. In this case, the repressors pass from the gametes to the zygotes for each gene of the trigger, and both will be turned off for sometime. Sequential cell divisions will dilute the repressors.

Eventually, some cells will accidentally contain repressors of one kind and the others will possess repressors of the other kind. Accordingly, the epigenotypes of some cells will be $C_{0} D^{1} / C_{0} D^{1}$, and those of the remaining cells will be $C_{1} D^{0} / C_{1} D^{0}$. The ratio of cells with different epigenotypes will depend on the relative concentration of the two kinds of repressors in zygote.

To illustrate the appearance of cells with different epigenotypes during a namber of cell division, we may take the simplest case. Let the repressor concentration in the zygote make up 4 molecules per cell for the gene $D$ and 2 molecules per cell for the gene $C$. The dilution of the repressors during subsequent sequential cell division is shown in Fig. 4. Each division will decrease the concentration of repressors per cell, on the average, by half until there emerge cells containing one molecule of each repressor. It is easily understood that shortly afterwards or with the completion of a certain number of divisions, cells with different epigenotypes

$$
C^{0} D^{1} / C^{0} D^{1} \text { or } C^{1} D^{0} / C^{1} D^{0}
$$

may be expected to form. The trigger system ensures constancy of each of these states during sequential cell division.

The kind of gamete epigenotypes of such organism depends on whether the reproductive pathway has been established prior to or after stabilization of the states

$$
C^{0} D^{1} / C^{0} D^{1}, C^{1} D^{0} / C^{1} D^{0} .
$$

Individuals with an early pathway establishment (individuals of the type I) will produce gametes of two kinds: $C^{0} D^{1}$ and $C^{1} D^{0}$. Individuals with a late (in the aforementioned sense) pathway establishment (individuals of the type II) will give rise either to gametes with $C^{0} D^{1}$ or to gametes with $C^{1} D^{0}$ epigenotypes only. In this case, the kind of gametes of the concrete individual is accidental.

Thus, depending on the peculiarities of the ontogenesis of partners, crosses between individuals with different epigenotypes $C^{1} D^{0} / C^{1} D^{0} \times C^{0} D^{1} / C^{0} D^{1}$ may yieid offsprings producing gametes of two kinds or offsprings producing gametes of one kind only. $\hat{C} \hat{D} / \hat{C} \hat{D}$ will be taken to designate epigenotypes of the offsprings producing gametes of two kinds and $\widetilde{C D} / \widetilde{C D}$-epigenotypes of the offsprings producing gametes of only one kind. For simplicity, we shall restrict ourselves to the operon $C$ of the trigger system. The active state of the operon $C$ is assumed to manifest itself phenotypically in the presence of a certain biochemical product. Hence, this product may be present in individuals with epigenotypes $\hat{C} / \hat{C}$ and $\widetilde{C} / \widetilde{C}$ which phenotypically will prove similar to individuals with epigenotype $C^{1} / C^{\mathrm{s}}$. Using the accepted designations, the outcome of crosses between individuals of the type I may be described as:

1. $C^{1} / C^{1} \times C^{0} / C^{0} \rightarrow \widehat{C} / \hat{C}-$ formation of a «hybrid»; 12. $\widehat{C} / \widehat{C} \times C^{1} / C^{1} \rightarrow \widehat{C} / \widehat{C} ; C^{1} / C$

3. $\widehat{C} / \widehat{C} \times C^{0} / C^{0} \rightarrow \widehat{C} / \widehat{C} ; C^{0} / C^{0}-$ analogue of the analysed cross;
4. $\hat{C} / \widehat{C} \times \widehat{C} / \widehat{C} \rightarrow C^{1} / C^{1} ; C^{0} / C^{0} ; \widehat{C} / \widehat{C}-$ splitting. 


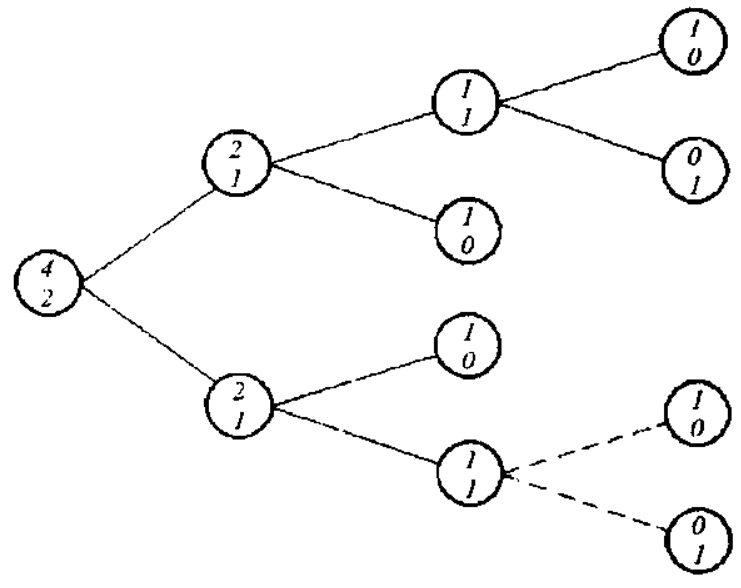

Fig. 4. Dilution of trigger repressors during zygote divisions (for explanations see text)

Thus, in this case, offsprings of three kinds with the same genotypes is possible. Such a behaviour of individuals $C / C$ during crosses let them to be referred to as epiheterozygotes. It may be easily seen that in the described situation the epigene «mimies» is a true gene. Actually, analogous phenotypes occur as a result of the crosses of the kind $1-4$, provided that instead of a pair of epigenes differing only in states, we take a pair of alleles $C$ and $c$ differing structurally.

It is obvious that individuals with epigenotypes $\mathcal{C} / \mathcal{C}$ cannot be regarded as epiheterozygotes, because each of them produces gametes of only one kind.

When individuals are crossed with epigenes containing different structural genes but having the same receptor zones,

$$
C_{1} D_{1} / C_{2} D_{2} \times C_{1} D_{1} / C_{2} D_{2},
$$

as a resuit of the combination of chromosomes and crossing-over, will yield 9 genotypical and 18 epigenotypical classes:

$$
\begin{aligned}
& C_{1}{ }^{1} D_{1}{ }^{0} / C_{1}{ }^{1} D_{f}{ }^{0} \text {, } \\
& C_{1}{ }^{1} D_{1}^{0} / C_{2}^{1} D^{0}{ }_{2} \text {, } \\
& C_{2}{ }^{1} D_{2}{ }^{0} / C_{2}{ }^{1} D_{2}{ }^{3} \text {, } \\
& C_{1}{ }^{1} D_{1}{ }^{0} / C_{1}{ }_{1}^{1} D_{2}{ }^{0} \text {, } \\
& C_{1} D_{1}{ }^{0} / C_{2}{ }^{1} D_{1}{ }^{0} \text {, } \\
& C_{1}{ }^{1} D_{2}{ }^{0} / C_{2}{ }^{1} D_{2}^{0} \text {, } \\
& C_{2}{ }^{1} D_{1}^{0} / C_{2} D_{2}{ }^{0} \text {, } \\
& C_{1}{ }^{1} D_{2}{ }^{0} / C_{1}{ }^{1} D_{2}{ }^{0} \text {, } \\
& C_{2}{ }^{1} D_{1}{ }^{\circ} / C_{2}{ }^{1} D_{1}{ }^{0} \text {, } \\
& C_{1}{ }^{0} D_{1}{ }^{1} / C_{1}{ }^{0} D_{1}{ }^{1} \text {, } \\
& C_{1}{ }^{0} D_{1}{ }^{1} / C_{2}{ }^{0} D_{2}{ }^{1} \text {, } \\
& C_{2}{ }^{0} D_{2}{ }^{1} / C_{2}{ }^{0} D_{2}{ }^{1} \text {, } \\
& C_{1}{ }^{0} D_{1}{ }^{1} / C_{1}{ }^{0} D_{2}{ }^{1} \\
& C_{1}{ }^{0} D_{1}{ }^{1} / C_{2}{ }^{0} D_{1}{ }^{1} \text {, } \\
& C_{1}{ }^{0} C_{2}{ }^{1} / C_{2}{ }^{0} D{ }^{1} \text {, } \\
& C_{2}{ }^{0} D_{1}{ }^{1} / C_{2}{ }^{0} D_{2}{ }^{1} \text {, } \\
& C_{1}{ }^{0} D_{2}^{1} / C I^{0} D_{2}{ }^{1} \\
& C_{2}{ }^{0} D_{1}{ }^{1} / C_{2}{ }^{0} D_{1}{ }^{1} \text {. }
\end{aligned}
$$

If $C_{2}$ and $C_{1}, D_{2}$ and $D_{1}$ are codominant, these epigenotypes correspond to six phenotypes. The crossing-over between $C$ and $D$ does not manifest itself phenotypically, because in each trigger one gene is turned off.
To conclude, we shall sum up the results of the analysis of crosses between individuals differing in epigenotypes only. The following events may be expected to occur in offspring from crosses between individuals containing epigenes in different states. The manner in which these events are manifest depends on the underlying epigene mechanisms and on the features of ontogenesis:

1. Absorption (offspring will have epigenes in the same states).

2. Formation of an epiheterozygote organism producing gametes of different kinds.

3. Formation of offsprings with each producing a gamete of one kind and individuals differing in the kind of the gametes produced.

Diagnostic Experiments and Some Facts. Let us describe the means which may be experimentally helpful in identification of the existence of epigenes. In the case of their existence, the functional state of some genes subordinated to epigenes can be changed, and this change will be inherited by subsequent generations though the structure of genes in itself has not changed. The phenomenon of absorption consisting in unification of states of genes subordinated to epigenes, observed as early as in the first generation, with a consequent absence of splitting may serve as a diagnostical feature of epigene existence. The situation is more complex when epigenotypes $\hat{A} / \hat{A}$ and $\tilde{A} / \bar{A}$ are formed. In cases like this the existence of epigenes may be identified in the following way. We assume the existence of some gene A subordinated to the epigene. The chromosome, wherein the gene $A$ is located, has the marker $M$ of the dominant gene coupled to the gene $A$. The idea of the experiment is to change the state of the gene $A$ through crossing and watch the behaviour of the marked chromosome. We assume the crosses: $A^{1} M / A^{1} M \times A^{0} / A^{0}$. Accordingly, depending on the type of partners, we shall have in the first generation either individuals $\widehat{A} M / \widehat{A}$ or $\widetilde{A} M / \mathcal{A}$. Let us examine the first case: $A^{1} M / A^{\prime} M \times$ $\times A^{0} / A^{0} \rightarrow \hat{A} M / \hat{A}$. The epiheterozygote will produce gametes of the following kinds: $A^{0} M, A^{1} M, A^{1}$ and $A^{0}$ including gametes, containing the marker and the gene $A$ in the state alternative to the initial one. Such gametes will occur in crosses:

$$
\widehat{A} M / \hat{A} \times A^{0} / A^{0} \rightarrow A^{0} M / A^{0} ; A^{0} / A^{0} ; \widehat{A} M / \hat{A} ; \widehat{A} / \widehat{A}
$$

with the resulting individuals $A^{0} M / A^{0}$ having the marker and the gene $A$ in an inactive state. Phenotypically, this will manifest as the absence of the effect of the gene $A$.

The analogous crosses between individuals with epigenotypes $\hat{A} M / \hat{A}$ and $A^{0} / A^{0}$ will also yield individuals $A^{0} M / A^{0}$. The formation of such individuals 
serves to indicate the existence of epigenes, because the change of state of the marked chromosome is the only way of their formation.

In the case of the absence of epigenes, the result of the experiments with individuals containing the marked chromosome will be as follows: $A M / A M \times$ $\times a / a \rightarrow A M / a$. Phenotypically, the individual $A M / a$ may look as individuals with epigenotypes $\hat{A} M / \widehat{A}$ and $\tilde{A} M / \tilde{A}$. However, after the second cross: $A M / a \times$ $\times a / a \rightarrow A M / a ; a / a$ the two types of individuals are formed. Individuals of the first type are characterized by the presence of the marker $M$ and the effect of the gene $A$, whereas those of the second type - by their absence.

The inheritance of nonmutational changes, induced by external agents, may also testify to the existence of epigenes. An illustrative case is the data obtained in studies of the effect of heat shock on the development of macrochaetae in the forked mutants of Drosophila melanogaster $[11,12]$.

Four critical periods have been established during development of macrochaetae. The first period includes the early stages of ontogenesis (some $6-7$ days before laying of eggs); the second includes the stage when eggs have been just laid; the third period is observed at the 14th hour of embryogenesis and the fourth refers to the prepupal stage of development (5th day of a larval life). Exposure to heat (or cold) during these periods, depending on the duration of thermal treatment, induces either a decrease (shortterm thermal treatment) or an increase (long-term treatment) in the number of abnormal macrochaetae. These changes are transmitted to a large number of successive generations. For example, warming of flies to $38{ }^{\circ} \mathrm{C}$ for 30 minutes at the first critical period decreases the number of abnormal macrochaetae, and this decrease is a maternally inherited character retained by twenty to thirty (sometimes, even more) subsequent generations $[12,13]$. Based on some definite arguments, Svetlov and Korsakova conclude that these changes are not mutations. The main argument used was the fact that the number of abnormal macrochaetae is reduced inall offspring from thermally treated parents.

The phenomenon of «absorption» is another diag nostic feature of epigene existence. Phenotypically, «absorption» resembles paramutations, which are the consequence of the heterozygous association of a paramutable allele with a paramutagenic allele; the resulting paramutable alleles are inherited by subsequent generations. Examples of paramutations are those occurring at locus $R$ in maize [13]. The three alleles at locus $R$ are $R^{r}, r^{g}$ and $R^{s t}$.

$R^{r}$ controls the formation of anthocyan in plants and in aleurone endosperm. The endosperm is triploid, because its cells receive a double set of genes from the maternal plant and a single set from the paternal one. The allele $R^{r}$ in a single dose $\left(R^{r} r^{g} r^{8}\right)$ gives rise to a dark-dotted aleurone a dark one-colour aleurone in a double or triple dose. The recessive allele $r^{g}$ is responsible for the absence of anthocyan in plants as well as in the aleurone. The alleles $R^{s t}$ gives a spotted pattern of the aleurone, the number of spots being proportional to the dosage of this allele. The existence of paramutations is illustrated by the following experiments. Three crosses are conducted:

1) $r^{g} r^{g} \circ \times R^{r} R^{T}$

2) $r^{g} r^{g} \circ \times R^{s t} R^{s t}$

3) $r^{g} r^{g} \circ \times R^{t} R^{s t}$.

The following endosperm genotypes are expected to occur:

1) all with $R^{r} r^{g} r^{8}$ genotype.

2) all with $R^{s t} r^{g} r^{g}$ genotype.

3) $50 \%$ with $R^{r} r^{g} r^{g}$ and $50 \%$ with $R^{s t} r^{g} r^{g}$ genotypes.

Spotted seeds with genotypes $R^{s t} r^{g} r^{g}$, expected from crosses 2 and 3 , do not differ phenotypically; all seeds with $R^{r} r^{g} r^{g}$ constitution, derived from crosses 1 and 3 , differ. All seeds with $R^{r} r^{g} r^{g}$ genotype derived from cross 3 , contain, on the average, half the pigment contained in seeds from cross 1 . The allele $R^{r}$, after heterozygous association with allele $R^{s t}$, passes into another state, designated as $R^{r} 1$. This change is inherited and manifests in decreased capacity for anthocyan formation. The $R^{r} \rightarrow R^{r} 1$ transition is a paramutational change. The phenomenological similarity between paramutation and absorption lies in the inheritance of one of its alleles after their heterozygous association with another allele. Paramutation leads to a functional change of the allele $R^{r}$, not a structural one, perhaps, because this allele falls into state $R^{r} 1$ in almost all the $R^{r}$ gametes in plants with $R^{r} R^{s t}$ constitution.

From an evolutionary point of view, the existence of epigenes, «the so to say second supplementary flux of hereditary information», might apparently give some advantages to their possessors. When epigenes are in inactive state, mutations of subordinated genes are not manifested and look quite neutral. Thus, accumulation of mutations, their realization and estimation through natural selection by switching on the respective epigenes is possible. Besides, the organism possessing epigenes would enable to approve different hereditary changes without changes of the genome, and this may serve as a material for natural selection.

To sum it up, we may conclude that epigenes are really existing in nature at least in $\lambda$-phage and other lambdoid phages. As for eukaryotes, though the 
existence of such systems is not shown experimentally, some facts may be successfully viewed from the standpoint of the epigene hypothesis. This hypothesis may prove to be useful to explain a number of data which cannot be explained within the frames of conventional Mendelian notions.

I am thankful to D. K. Belyaev, M. D. Golubovski, E. V. Gruntenko, L. I. Korochkin, V. A. Kulichkov, Z. S. Nikoro, V. A, Ratner and V. V. Khvostova for their constructive discussion and valuable criticism, of the paper and I acknowledge the technical aid rendered by G. Kh. Ziganshina and I. G. Migranova.

Гіпотеза про еліген

P. H. Yypace

Резюме

Запропоновано сіпотезу про епісен - одиницю, у якій: а) спадкова інформація кодусться не лище послідовностями основ у молекулах ДНК, але й іниим способом, наприклаd, присутністю або відсутністю визначених регуляторних білків; б) зберісання спадкової інформації протягом життя клітини забезпечується наявністю зворотних зв'язків; в) передача спадкової інформацї від батьківської особини до нащадків здійснюється илляхом розподілу позагеномних макромолекул ресулюючих речовин. Розглянуто моделі найпростіших систем з ознаками епісена. При схреиуванні особин, що містять епіген у різних станах в залежності від конкретного виду епігена та особливостей онтогенезу, у потомстві від схрещувань можуть статися наступні події: поглинання (нашадки матимуть епісени в однакових станах); 2) виникнення епіzетерозиготи, яка дає гамлети різних сортів; 3) формування таких особин, кожна з яких виробляе лище один сорт гамет, але різні особини здатні виробляти різні сорти гамет. Запропоновано ідею експеримента, що дозволяє виявити епігени иляхом схрещування.

Гипотеза об эпигене

\section{P. H. Чураев}

Резюме

ПТредложена сипотеза об эписене-единице, в которой: a) наследственная информация кодируется не только последовательностью оснований в молекулах ДНК, но и другим способом, наприхер, присутствием или отсутствием определенных ресуляторных белков; б) хранение наследственной информации в течение жизни клетки обеспечивается наличием обратных связей; в) передача наследуемой информации от родительской особи к потомству прочсходит путем распределения внегеномных макромолекул регулирующих веществ. Рассмотрены модели простейщих систем, обладаюицх свойства- ми эпигена. При скрещивании особей, содержащих эписены о разных состояниях в зависимости от конкретного вида эпигена и особенностей онтогенеза, в потомстве от скрещиваний могут произойти следующие события): 1) поглощение (потомство будет иметь эпигены в одинаковых состояниях; 2) образование эпигетерозиготы, дающей самлеты разных сортов; 3) образование таких особей, кахдая из которых производит лищь один сорт гамет, но разные особи могут производить разные сорта гамет. Предложена идея эксперимента, позволяющего выявить эпигены путем скрещиваний.

\section{REFERENCE}

1. Ratner V. A., Tchuraev R. N. Does a two-operon control system (trigger) exist? Some facts and the heuristic importance of the trigger // Genetika.-1971.-7, N 9.-P. 175-179.

2. Oppenheim A. B., Neubauer Z., Calef E. The antirepressor new element of the regulation of protein synthesis // Nature.1970.-226, N 5240.-P. 31 .

3. Nijkamp H.J. J., Szybalski W., Calef E. Antirepressor controls tetranscription of the repressor operon of lambda phage // Informative Molecules in Biology Systems.-Amsterdam: NorthHolland Publ. Co., 1971.-P. 241

4. Tchuraev $R$. N., Ratner $V$. A. About operon system modelling in the language of automata theory // Genetika. - 1971.-9, N 2.-P. 173 .

5. Echols H., Green $L$. Establishment and maintence of repression by bacteriophage lambda: the role of the $C_{1}, C_{11}$ and $C_{111}$ proteins // Proc. Nat. Acad. Sci. USA. $-1971 .-68, N 9 .-$ P. 2190.

6. Davidson $E$. Gene activity in early development.-Moscow: Mir, 1972.

7. Riggs A. D., Bourgeois S., Cohn $M$. The lac-repressoroperator interaction. III. Kinetic studies // J. Mol. Biol.1970.-53, N 3.-P. 401.

8. Monod J., Jacob $F$. General conclusions: teleonomic mechanisms in the processes of cell metabolism, growth and differentiation // Regulatory Mechanism of the Cell.-M.: Mir, 1964.-P. 477

9. Romanovski Ju. M., Stepanova N. V., Chernavski D. S Mathematicai modelling in biophysics.-M.: Fismatgiz, 1975.

10. Tchuraev $R$. N., Ratner $V$. A. Modelling of molecular and genetic control systems in the language of automata theory // Studies on Theoretical Genetics.-Novosibirsk: Inst. Cytol. Genet. Press, 1972. $-210 \mathrm{p}$.

11. Svetlov $P . G$., Korsakova $G$. $F$. Effect of the short-term heating of the forked female mutants of Drosophila melanogaster on the expressivity of characters of the mutation in a number of subsequent generations // Dokl. Acad. Nauk SSSR. -1966 . 168, N 1.-P. 191.

12. Svetlov $P$. G., Korsakova $G$. $F$. Long-term modification in the experiments with thermally treated larvae of the forked mutants of Drosophila melanogaster // Ibid.-170, N2.-P. 439.

13. Brink R. A., Styles E. D., Axtell J. D. Paramutation: directed genetic change // Science.-1968.-159, N 3811.-P. 161.

УдК 575.17

Received 26.02.96 